How to cite this article:

Krishnaswamy, J., Seow S. K., \& Annamalai, N. (2019). The shadow education system: Students' responses to private tutorial learning. Malaysian Journal of Learning and Instruction, 16(2), 201-225.

\title{
THE SHADOW EDUCATION SYSTEM: STUDENTS' RESPONSES TO PRIVATE TUTORIAL LEARNING
}

\author{
${ }^{1}$ Jayaraman, K, ${ }^{2}$ Seow Soo Koon \& ${ }^{3}$ Nagaletchimee Annamalai \\ ${ }^{\prime}$ Taylor's Business School, Taylor's University, Subang Jaya, \\ Selangor, Malaysia \\ ${ }^{2}$ Graduate School of Business, Universiti Sains Malaysia, Malaysia \\ ${ }^{3}$ School of Distance Education, Universiti Sains Malaysia, \\ Malaysia
}

${ }^{I}$ Corresponding author: jayaraman.krishnaswamy@taylors.edu.my

Received: 28/10/2018 Revised: 1/8/2019 Accepted: 27/9/2019 Published: 24/12/2019

\section{ABSTRACT}

Purpose - In Malaysia, numerous families devote a portion of their income to private tutorial learning fees. Many parents, especially those who stay in urban areas, send their children for private tutorial learning. This research investigated the challenges of a shadow education system by analysing Malaysian secondary school students' reactions to private tutorial learning.

Methodology - A survey instrument with a structured questionnaire was designed on a webpage and delivered via email and Virtual Learning Environment through Frog Asia, which is the first company to connect Malaysian schools through a single cloud-based learning platform. The online survey approach was chosen as a convenient and cost effectiveness means of interacting with respondents who were dispersed in various geographical locations across the country. 148 respondents from three Malaysian states, Penang, Perak and Johor, were identified using convenience sampling. 
Findings - The results showcase the reasons for choosing private tutoring from both students' and parents' perspective. Significant findings revealed that the factors influencing students' choice to attend private tutorial learning were the school environment, social influence, rigidity of the school system, students' learning attitude and affordability for parents. The study also indicated that parents were exercising excessive force on students' academic choices, which increased tension and anxiety among their children. Parental influence can be stressful and have a traumatic impact on children's learning abilities. Furthermore, it was found that students were missing extra-curricular activities.

Significance - The secondary school syllabus is too crammed and its scope is too wide, leading school teachers to complete it without in-depth teaching and learning activities. Due to peer influence, private tuition becomes a routine activity, causing school students to miss extra-curricular activities. Ultimately, a good outgoing school student is a potential candidate for higher education, and educationally qualified and skilled persons are needed for the future economy of Malaysia. It is suggested that education policy makers should not introduce a rigid curriculum as rigidity leads to rote learning and produces poorly talented children.

Keywords: Private tutorial learning, students' reactions, social influence, rigidity of school system, affordability.

\section{INTRODUCTION}

In recent years, private tuition or tutoring (PT) has become a burgeoning phenomenon in many parts of the world. In many countries, private tutorial learning is seen as a form of shadow education and its significance is indisputable. In PT, the tutor teaches an academic subject for a fee (Dang \& Rogers, 2008; Bray, 1999). Parents are keen to send their children for tutoring as they strongly believe that tutoring would help them to excel in examinations. According to statistics from the Malaysian Ministry of Education, in 2013 there were 3,107 registered private tutoring centres in Malaysia, with 3.2 percent of the total number of primary and secondary students enrolled, and 11,967 teachers (Ministry of Education Malaysia, 2013). The common types of private tutorial 
learning in the market for many countries include (i) one-to-one private tutorial teaching, (ii) school teachers who teach students after daily school, and (iii) professional private tutors who set up classrooms and operate the business by providing lectures to students.

Past studies have offered several reasons for the PT phenomenon. A study conducted in Korea by Kim and Park (2007) reported that the need for admission to universities was the principal reason for students to enrol in PT. Ireson and Rushforth (2005) argue that three main reasons parents send their children for PT are for them to gain self-confidence, acquire a better understanding of a particular subject and score excellent grades in their examinations. In the Malaysian scenario, socio-demographic characteristics seem to play a crucial role in the participation of students in PT (Das \& Das, 2013; Kim \& Lee, 2004). A study by Jelani and Tan (2012) found that ethnicity, income, level of schooling and marital status influenced the participation of students in PT. Nevertheless, a more insightful investigation of PT in the local context is needed. Previous studies have not focused on the perception of students on private tutoring in Malaysia. Realizing this, the current study aimed to contribute towards further understanding of students' PT choices in the context of Malaysian educational policies. It is hoped that the findings of this study would add substantially to the growing pool of research in the area of PT and policy makers.

Unlike teachers in other countries, Malaysian school teachers are allowed to tutor outside school hours to supplement their income (Ministry of Education Malaysia, 2006). In this information technology era, a person who wants to be successful in life must acquire the skills and commitment to continue to educate himself or herself with new information (Shah \& Farooq, 2009). Quality assurance is becoming an imperative issue, discussed by both the government and educational institutions (Ali, Isa \& Ibrahim, 2011). Students seem to have the wrong perception that the most important thing in examinations is to achieve the highest score and excellent results. They also believe that private tutors can help them in many aspects such as academic learning, life guidance and future planning (Goold, Coldwell \& Craig, 2010). Today, tuition classes have grown rapidly and become necessary among secondary and primary school students. 
According to Global Industry Analysts (GIA), the global market for private tutorial learning is estimated to have increased to $\$ 102.8$ billion by 2018 (Crotty, 2012). The huge market is due to the issue of the failure of education systems, which are unable to fulfil students' needs and parents' desire to provide a better education for their children to gain global competitive advantage. The GIA showed that the United States, Europe and the Asia-Pacific (especially Hong Kong, South Korea, Japan, Singapore and China) provided more than $90 \%$ of global private tutorial learning. This implies that in the present education system, schools have deficiencies such as a lack of personal contact, no special guidance for academically weaker students, more focused on heavy syllabus coverage, less practical (lab) exposure and issues pertaining to large class size. While some argue that private tutorial learning creates pressure on students' lives, another viewpoint is that the money spent could be solving the failure of the education system. In Malaysia, many families devote a portion of their income to private tutorial learning fees. Many parents, especially those residing in urban areas, send their children for private tutorial learning. From the perspective of parents and students, private tutorial learning improves the children's knowledge and examination scores (Gök, 2010). At the same time, Economides, Philippopoulos and Sakkas (2017) opined that the affordability of tuition fees affects the revenue generation of private schools. The Malaysian education system is meritocratic and competitive. Students have to compete to enrol in public universities, to get scholarships, and to gain a chance to further their studies overseas. Yan-Li, Roslan, Abdullah, and Abdullah (2018) suggest that families play a crucial role in adolescent school performance.

\section{LITERATURE REVIEW}

Private tutorial learning is a supplement to school teaching (Bray, 1999; Hon, 2010). It is considered a learning institution that helps to improve underperforming students' achievement of academic learning (Burns, Senesac, \& Symington, 2003). According to McArthur, Stasz and Zmuidzinas (1990), private tutors who are most successful often apply well-rehearsed scripts in their teaching. PT is also found to be successful when related to classroom instruction. For example, when a tutorial class is conducted with good classroom reading practices, students can perform better in 
terms of academic achievement compared to an environment which is unrelated to classroom instruction (Venezky \& Jain, 1996). The school is a place to provide cognitive development for student learning. In schools, teaching methods are updated to ensure that teachers provide effective teaching and students get a good learning environment. For example, according to the American Association of School Librarians (1998), the school achieves its objectives by adapting a suitable media program in the library. The students have to find their own way in order to strengthen their learning skills. This will encourage them to perform and react well in school (Candeias, Rebelo, \& Oliveira, 2008).

Peer pressure is a powerful influence among teenagers. Students who have good social networking skills are more likely to perform better academically (Colvin \& Ashman, 2010). Peers are able to influence each other in a positive manner (Steinberg, 1996). In fact, Abdullah, Salim, and Arip (2018) reported that peer influence is one of the factors that influences truancy in schools. According to Ha and Harpham (2005) there is a contextual effect of one parent's need to send her child for private tutoring on other parents' need to do the same. This effect was analysed by observing the percentage of schoolmates who received private tutorial learning. According to Perkins, Adams, Pollock, Finkelstein, and Wieman (2005), students who have good appearance and behaviour perform better in their academic learning. It is also possible to create a better environment to improve student learning attitudes so that they can focus on their learning. In addition, Perkins et al. (2005) stated that students' concentration highly influenced their learning improvement.

The reasons students enrol themselves in private tutorial learning are to increase the understanding of their lessons and to gain a higher score in examinations (Dang \& Rogers, 2008). Ha and Harpham (2005) emphasized that private tutorial learning can improve children's reading skills, writing and multiplication scores. Tutoring programs have been developed to overcome the deficits of education systems (Marsh, 2001) and improve overall academic performance (House \& Wohlt, 1990). Parents are trying their best to fulfil their children's educational needs (Tsang \& Levin, 1985). Thus, students' reactions to private tutorial learning lead to many questions regarding its significance. 


\section{General School Environment and Students' Favouring for Private Tutorial Learning}

The general school environment may contribute to students favouring learning in private tutorials. During school time, some students do not focus on the topics and contents of books. The teacher may be teaching certain topics that the students have already studied in private tutorials, or he or she has less time to teach difficult topics. Some school teachers who are keen to conduct private tutorial lessons outside after school may not teach well during school time. According to Ille and Peacey (2019), to avoid private tutoring, education polices should emphasize on social acceptance, incentives and accountability, and at the same time should not expect better teaching quality by merely increasing a teacher's salary. Bray and Kwok (2003) point out that some tutors who still teach in mainstream schools have explicitly stated that they see themselves as catering to clients in a market place in a way that is not the norm in the school system. Thus, the following hypothesis is developed:

H1: The General School Environment negatively influences students' favouring for private tutorial learning.

\section{Social Influence and Students' Favouring for Private Tutorial Learning}

Peer influence among secondary school students is one of the crucial reasons for private tutorial learning. A group which is more cohesive will have greater influence among its members (Dougherty \& Hammack, 1990). Hence, peers can influence students to take private tuition classes, which might create less academic aspirations towards the mainstream school (Gara \& Davis, 2006; Colvin \& Ashman, 2010). Guidance psychologists have shown that during adolescence, the influence of social background on aspirations increases dramatically (Dupriez, Monseur, Van Campenhoudt, \& Lafontaine, 2012). Further, Dupriez et al. (2012), state that during the teenage years of schooling, social background, educational or professional aspirations and academic performance are strongly related to each other. Also, in most Malaysian families, both parents work and therefore have no other choice but to leave their wards to the tuition centre. Thus, the following hypothesis is developed:

H2: Social influence positively relate to students' favouring for private tutorial learning. 


\section{Rigidity of the School System and Students' Favouring for Private Tutorial Learning}

Gordon, Morgan, Ponticell, and O'Malley (2004) suggest that the most effective private tutorial learning has been to use teachers who can continuously collaborate with students. Tutors who have daily contact with students will be able to facilitate communication about the curriculum and have an impact on students' performance. Some private tutorial classes establish good rapport with their students. Moreover, the classes are scrutinized by the children's parents, and this can help in monitoring and encouraging attendance. By doing so, tutors provide good tutoring services and build up strong relationships between classroom instruction and curriculum. Thus, new and poorly-structured tutors have disadvantages compared with those who have established good relationships with students. An analysis by Cohen, Kulik, and Kulik (1982) found that private tutorials that are well-structured can be more successful (Cohen et al., 1982). Thus, the following hypothesis is developed:

H3: Rigidity of the school system positively influences students' favouring for private tutorial learning.

\section{Students' Learning Attitude and Students' Favouring for Private Tutorial Learning}

Along with linguistic diversity, students in Malaysia have to diversify learning styles which have been formed through prior cultural and learning experiences (Bohan, 2007). Students have their own learning styles. Students with self-esteem and highlymotivated students actively seek private tutoring (Bray \& Kwok, 2003). Others who are less motivated may be forced to enrol in PT by their parents or teachers, and even peer-pressured by their friends (Bray \& Kwok, 2003; Soh, Jayaraman, Lim, \& Chong 2012; Bray, 2013). Students who perform below average in tests and assignments also have the intention to enrol in private tuition classes. Therefore, in order to adapt to the educational system in Malaysia, students seek private tuition classes, even multiple private tuition classes for many subjects throughout their school years. Thus, the following hypothesis is developed:

H4: Students' learning attitude negatively influences students' favouring for private tutorial learning. 


\section{Moderating Effect of Parents' Affordability}

Parents' affordability refers to being within the financial means of parents. According to Qian (2014), receiving tutoring may become a financial burden, especially for poor families. The cost of education is increasing at a dramatic rate compared to manufacturing (Kim, 2007). PT becomes an important financial commitment for parents who want their children to have it. Parents believe that hiring tutors is a wider strategy to obtain premium education and a better study environment for their children (Bray, 2010). A careful plan will be structured by parents for this purpose. Although they know that their children may experience pressure for taking the various the private tuition classes, they believe that it is a worthwhile investment for the future (Bray, 2010). Pallegedara and Mottaleb (2018) noted that in Bangladesh, households kept a separate budget for private tutoring and the concept of private tutoring has been expanding over the years. Thus, the following hypothesis is developed:

H5: Parents' affordability has a positive influence on students' reactions to private tutorial learning.

Every school has a different approach in engaging students to excel in examinations (Tansel, 2012). Schools differ widely in terms of the quality of education they provide. There are school teachers who always emphasize on memorizing and remembering the answers and formats of examinations (Gök, 2010). Thus, inequality among schools increases students' desire for private tutorial learning. Unfortunately, not every student would have the chance to join private tutorial classes as it is much related to financial affordability (Tansel, 2012). Students who are from affluent families are privileged to select better private tutorial classes. Thus, the following hypothesis is developed:

H6a: Parents' affordability moderates the relationship between general school environment and students' reactions to private tutorial learning.

Parents send their children for private tutorial learning to improve their children's learning approaches (Dang \& Rogers, 2008). Unfortunately, some parents send their children to a private tutor just because their children fail to compete with their friends' 
children. Parents claim that their children lack motivation to learn (Hon, 2010), and believe that tutors are capable of teaching and upgrading them in this regard. According to Sujatha (2014), due to social problems, parents in urban areas of India provide private tutorial learning and put pressure on their children to score higher grades. These parents have a better educational background and good economic conditions, and are capable of providing PT for their children.

H6b: Parents' affordability moderates the relationship between social influence and students' reactions to private tutorial learning.

Parents who pay more attention to their children's education will strongly help their children to achieve better performance in school (Dang \& Rogers, 2008). Kim and Lee (2010) point out that parents try to use private tutorial learning to compensate for the deficient quality of the public education system. While the main purpose of the school is not merely to prepare for examinations, there is still a gap between the examination system and the school teacher's teaching conditions. Therefore, many parents seek PT for their children to excel in examinations.

H6c: Parents' affordability moderates the relationship between rigidity of the school system and students' reactions to private tutorial learning.

According to one private tutor, private tutorial learning can help in correcting his students' bad attitude and behaviour (Hon, 2010). Parents send their children for private tutorials to change their children's bad behaviour and improve their examination grades, which can help them to transform into future economic capital (Bourdieu, 2002). They send their children for private tutorial learning to take care of the children's individual needs such as emotional, behavioural, physical and mental problems. Parents also believe that their children will be safer if they are sent for private tutorial learning. Moreover, the children will not waste time doing unbeneficial activities at home (Sujatha, 2014). Parents would rather spend more money just to occupy their children's free time. Thus, the following hypothesis is developed:

H6d: Parents' affordability moderates the relationship between students' learning attitude and students' reactions to private tutorial learning. 
The conceptual research framework of the present study is depicted in Figure 1.

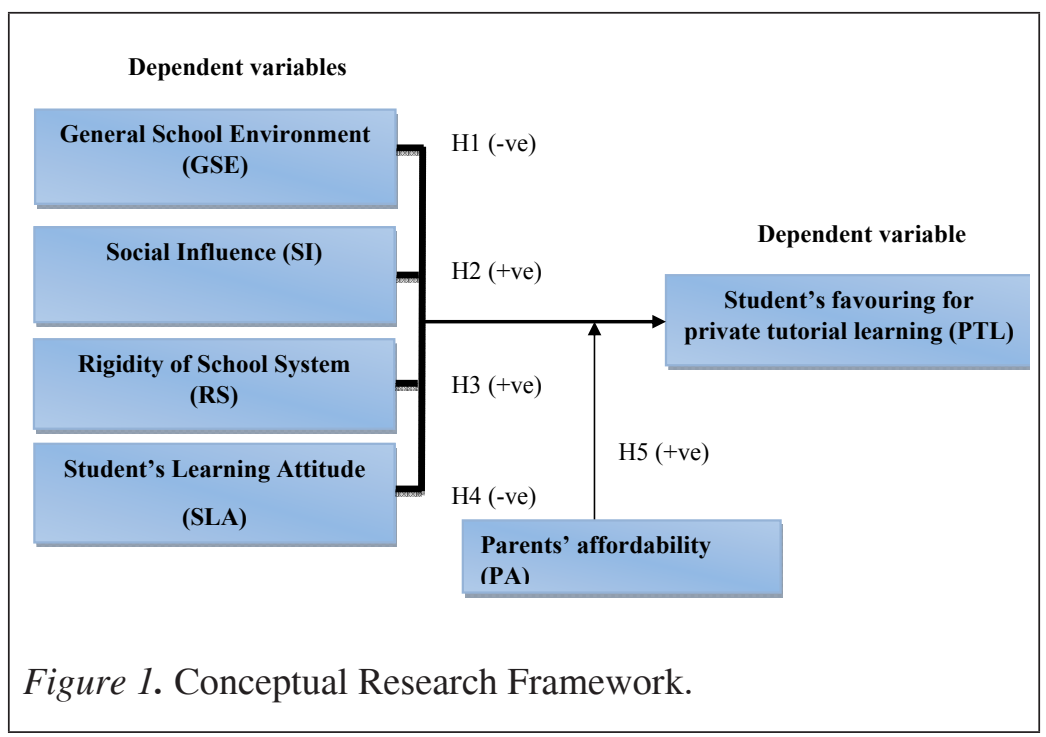

\section{RESEARCH METHODOLOGY}

Based on an extensive literature review, a survey instrument with a structured questionnaire was designed and published on a webpage, and delivered via email and a Virtual Learning Environment (VLE) named FROG. Frog Asia is the first company to connect Malaysian schools through a single, cloud-based learning platform. The online survey approach was used due to its convenience and cost effectiveness for interacting with Malaysian students in Forms 1 to 6 and undertaking tuition, who were considered the target population. The study covered different geographical locations across East and West Malaysia. The unit of analysis of the study was an individual. A first come first served basis was adopted after getting concurrence from the students. Convenience sampling technique (non-probability sampling) was used to identify 148 school students. The independent variables in this research were students' learning attitude, social influence, general school environment and rigidity of the school system. Students' favouring for private tutorial learning formed the dependent variable. There were five variables in the framework; for each variable a minimum of 10 respondents should be included for 
a representative sample (Nunnally \& Bernstein, 1994). In the online survey form, the independent variables were measured on a 5-point Likert scale, with 1 being "strongly disagree" and 5 being "strongly agree". The dependent variable was measured on a 7-point Likert scale, with 1 being "strongly disagree" and 7 being "strongly agree". The collected data were analysed using the Statistical Package for Social Sciences (SPSS) version 23 to generate descriptive analysis, factor analysis, reliability analysis, correlation matrix and multiple regression for goodness of data and for hypotheses testing.

\section{RESULTS}

As shown in Table 1, the 148 respondents were represented by 62 (41.9\%) boys and $86(58.1 \%)$ girls. In terms of school level, $52 \%$ of the students were from lower secondary (Forms 1-3) and $48 \%$ were from upper secondary (Forms 4-6). The composition of students by ethnicity were $21.6 \%$ Malay, $62.8 \%$ Chinese, $14.2 \%$ Indian and $1.4 \%$ from other ethnic groups. With regards to family annual income, $41.9 \%$ had an income of less than RM24000, and $28.4 \%$ were earning between RM24001 and RM42000. 18.2\% of families had an income of between RM42001 and RM60000, while 11.5\% earned more than RM60000 annually. Among the 148 students, $48.6 \%$ were attending PT for less than 5 hours per week, $39.9 \%$ of students attended for 5 hours- 10 hours per week; $8.8 \%$ attended for 11 hours-15 hours per week, while $2.7 \%$ had PT for more than 15 hours per week. As for the amount spent on monthly tuition fees, $50 \%$ of the students spent between RM100-RM200 per month; $25.7 \%$ spent RM201-RM400, 11.5\% students spent RM401-RM600 and $12.8 \%$ spent more than RM600 per month.

Table 1

Profile of Respondents $(n=148)$

\begin{tabular}{llcc}
\hline \multicolumn{1}{c}{ Variable } & Particulars & No. of Respondents & $\%$ \\
\hline Gender & Male & 62 & 41.9 \\
& Female & 86 & 58.1 \\
\multirow{2}{*}{ Secondary school level } & Forms 1 - 3 & 77 & 52.0 \\
& Forms 4 - 6 & 71 & 48.0 \\
\hline
\end{tabular}

(continued) 


\begin{tabular}{|c|c|c|c|}
\hline Variable & Particulars & No. of Respondents & $\%$ \\
\hline \multirow[t]{4}{*}{ Ethnicity } & Malay & 32 & 21.6 \\
\hline & Chinese & 93 & 62.8 \\
\hline & Indian & 21 & 14.2 \\
\hline & Others & 2 & 1.4 \\
\hline \multirow[t]{4}{*}{ Annual Family Income } & $<$ RM24 000 & 62 & 41.9 \\
\hline & $\begin{array}{l}\text { RM24 } 001- \\
\text { RM42 } 000\end{array}$ & 42 & 28.4 \\
\hline & $\begin{array}{l}\text { RM42 } 001- \\
\text { RM60 } 000\end{array}$ & 27 & 18.2 \\
\hline & > RM60 000 & 17 & 11.5 \\
\hline Time Spent on Private & $<5$ hours & 72 & 48.6 \\
\hline \multirow[t]{3}{*}{$\begin{array}{l}\text { Tutorial Learning (per } \\
\text { week) }\end{array}$} & $\begin{array}{l}5 \text { hours }-10 \\
\text { hours }\end{array}$ & 59 & 39.9 \\
\hline & $\begin{array}{l}11 \text { hours }-15 \\
\text { hours }\end{array}$ & 13 & 8.8 \\
\hline & $>15$ hours & 4 & 2.7 \\
\hline \multirow[t]{4}{*}{$\begin{array}{l}\text { Monthly Tuition Fees } \\
\text { (per subject) }\end{array}$} & $\begin{array}{l}\text { RM100 - } \\
\text { RM200 }\end{array}$ & 74 & 50.0 \\
\hline & $\begin{array}{l}\text { RM201 - } \\
\text { RM400 }\end{array}$ & 38 & 25.7 \\
\hline & $\begin{array}{l}\text { RM401 - } \\
\text { RM600 }\end{array}$ & 17 & 11.5 \\
\hline & $>$ RM600 & 19 & 12.8 \\
\hline
\end{tabular}

\section{Factor Analysis and Reliability Analysis}

According to Hair, Sarstedt, Matthews and Ringle (2016), factor analysis plays a pivotal role in making an empirical assessment of the dimensionality of a set of items by determining the number of factors and the loadings of each variable on the factors. The eight dimensions of General Social Environment (GSE) were named GSE1, GSE2, GSE3, GSE4, GSE5, GSE6, GSE7 and GSE8. Social Influence (SI) had five dimensions: SI1, SI2, SI3, SI4, SI5, while RS1, RS2, RS3, RS4, RS5 and RS6 were the six dimensions for Rigidity of the School System (RS). Students' learning attitude (SLA) had six dimensions, namely SLA1, SLA2, SLA3, SLA4, SLA5, and SLA6. The Eigenvalues were more than 1 for all factors 
and $\mathrm{KMO}$ was 0.745 which was highly acceptable, as the thumb rule is more than 0.5 (Hair et al., 2016). Hence the sample size was adequate and the significance of Bartlett's test of Sphericity proved the goodness of model fit. The total variance explained was $62.78 \%$, which exceeded the minimum recommended value of $60 \%$ (Hair et al., 2016). Besides that, the reliability analysis indicated that all latent variables GSE, SI, RS and SLA demonstrated high Cronbach's Alpha (above 0.7) except for SI (0.676); therefore, the question items were highly correlated and consistent within the variable (see Table 2). This reflected that the items measuring each variable had sufficient reliability and indicated that the items were highly inter-connected with each other within the factor.

Table 2

Factor Loadings for all Model Variables

\begin{tabular}{|c|c|c|c|c|c|c|}
\hline & \multicolumn{4}{|c|}{ Independent Variables } & \multirow[t]{2}{*}{$\begin{array}{l}\text { Variance } \\
\text { Explained }\end{array}$} & \multirow[t]{2}{*}{$\begin{array}{l}\text { Cronbach's } \\
\text { Alpha }\end{array}$} \\
\hline & 1 & 2 & 3 & 4 & & \\
\hline $\begin{array}{l}\text { Students' } \\
\text { Learning } \\
\text { Attitude } \\
\text { (SLA) }\end{array}$ & & & & & 27.201 & 0.833 \\
\hline SLA6 & 0.889 & & & & & \\
\hline SLA5 & 0.738 & & & & & \\
\hline SE5 & 0.724 & & & & & \\
\hline SLA4 & 0.720 & & & & & \\
\hline SLA3 & 0.647 & & & & & \\
\hline SLA1 & 0.594 & & & & & \\
\hline $\begin{array}{l}\text { Rigidity of } \\
\text { School } \\
\text { System (RS) }\end{array}$ & & & & & 15.518 & 0.762 \\
\hline $\mathrm{RS} 3$ & & 0.774 & & & & \\
\hline RS4 & & 0.764 & & & & \\
\hline RS1 & & 0.738 & & & & \\
\hline RS5 & & 0.671 & & & & \\
\hline $\begin{array}{l}\text { General } \\
\text { School } \\
\text { Environment } \\
\text { (GSE) }\end{array}$ & & & & & & \\
\hline
\end{tabular}




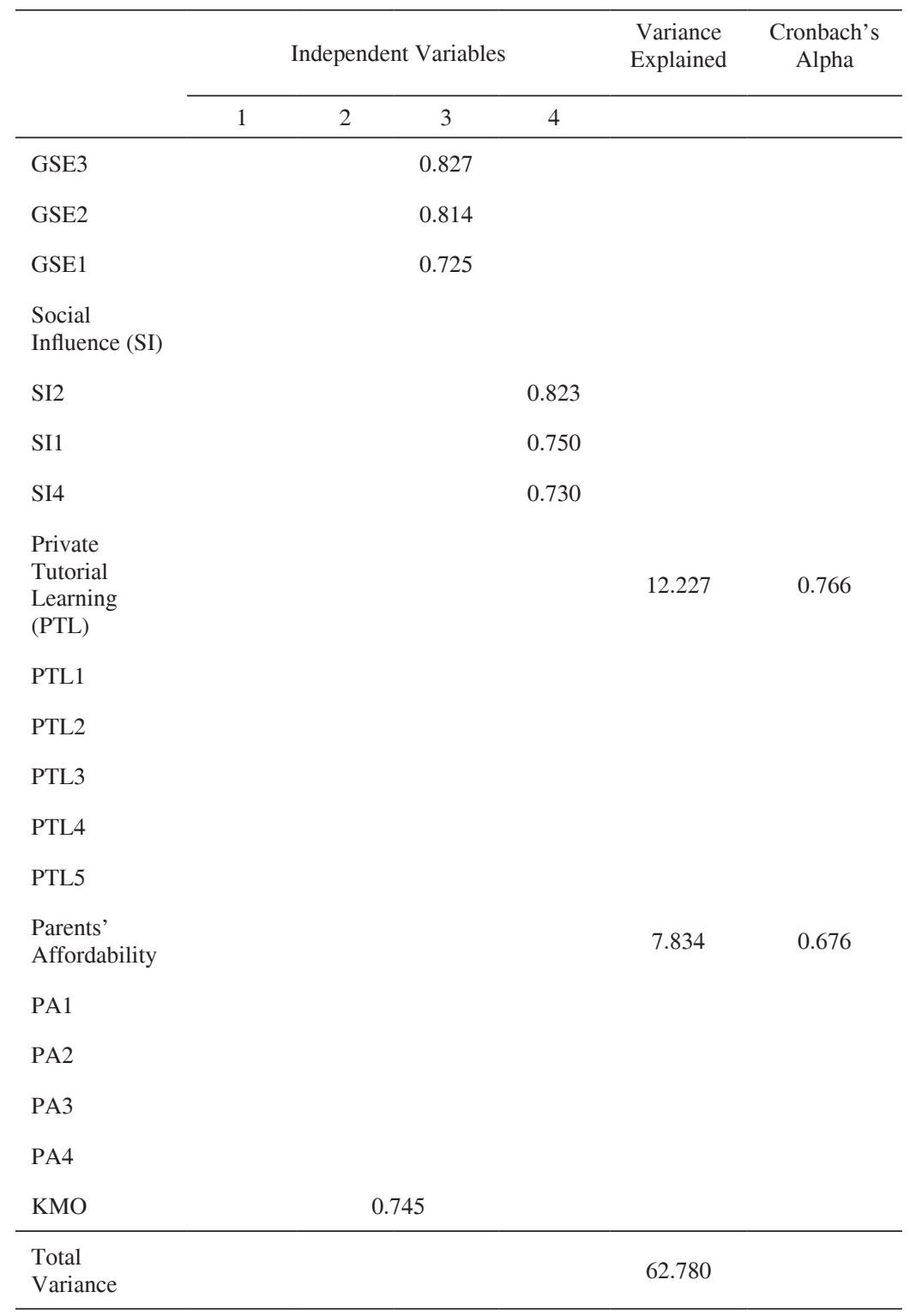

Note: SLA2, RS2, RS6, GSE4, GSE5, GSE6, GSE7, GSE8, SI3 and SI5 were deleted due to high cross loadings.

The results of factor loadings for the dependent variable (DV), namely students' favouring for private tutorial learning, show that the main loadings were more than 0.5 and the KMO was 0.737 . The significance of Bartlett's test of Sphericity established a good model fit. Further, the items were highly inter-correlated with each other 
since the Cronbach's Alpha was 0.864, which was greater than the thumb rule value of 0.7 (Hair et al., 2016). As for the moderating variable (MV), i.e., parents' affordability, it was found that all the factor loadings for the question items were more than 0.5 and the $\mathrm{KMO}$ was 0.670 , which was greater than minimum acceptable value of 0.5 , with a significant value for the Bartlett's test of Sphericity. All the items were highly inter-correlated with each other; the Cronbach's Alpha was 0.714, which was greater than the minimum value of 0.7 .

\section{Descriptive Analysis}

Table 3

Descriptive Statistics and Correlation Matrix of the Latent Variables $(n=148)$

\begin{tabular}{crrrrrrrrr}
\hline Variable & Mean & SD & SLA & RS & SE & SI & PA & PTL & VIF \\
\hline SLA & 2.744 & 0.823 & 1 & & & & & 1.143 \\
RS & 3.421 & 0.875 & $0.303^{* *}$ & 1 & & & & 1.329 \\
SE & 3.230 & 0.880 & $0.220^{* *}$ & $0.415^{* *}$ & 1 & & & \\
SI & 2.960 & 1.112 & -0.075 & -0.014 & 0.109 & & & 1.245 \\
PA & 3.644 & 0.850 & $0.174^{*}$ & $0.235^{* *}$ & 0.134 & & 1 & & 1.085 \\
PTL & 4.504 & 1.438 & -0.036 & $0.161^{*}$ & 0.106 & $0.471^{* *}$ & & 1 & \\
\hline
\end{tabular}

$* * \mathrm{p}<0.01 ; * \mathrm{p}<0.05$

Table 3 shows the descriptive statistics for the independent variables, dependent variable and moderating variable. As pointed out earlier, both the independent variables and the moderating variable were measured on a 5-point Likert scale, while the dependent variable was measured on a 7-point Likert scale. The mean for the dependent variable, students' intention to attend private tutorial learning (PTL), had a value of 4.504, with a standard deviation of 1.438 on a 7-point scale. The independent variable students' learning attitude (SLA) had the lowest mean value of 2.744 and a standard deviation of 0.823 , while rigidity of the school system had the highest mean 
value of 3.421 on a 5-point scale. The correlation values for all the independent variables (IVs) were below 0.6 , which clearly indicated that no multicollinearity issue existed among the IVs. Rigidity of the school system, school environment, social influence and parents' affordability were found to have positive correlations with students' intention to attend private tutorial learning. Students learning attitude had a negative correlation with the students' intention to attend private tutorial learning (DV), although it was not found to be significant. The Variation Inflation Factor (VIF) for all the independent variables was less than five (5), which indicated that there was no multicollinearity among the independent variables (Hair et al., 2016).

\section{Multiple Regression Analysis}

The multiple regression model satisfied the normality and linearity properties without any outliers in the data. Model-1 in Table 2 indicates the results of the multiple regression analysis for the independent variables on the dependent variable. This multiple regression model fits well to the data with the explainable variation $\mathrm{R}^{2}=0.253, \mathrm{~F}=12.109, \mathrm{p}<0.01$. The results reveal that social influence $(\beta=0.471, \mathrm{t}=6.432 \mathrm{p}<0.01)$ and the rigidity of the school system ( $\beta=0.190, t=2.319, p<0.05)$ were found to be statistically significant and positively influencing the student's favouring for private tutorial learning. Hence, $\mathrm{H} 2$ and $\mathrm{H} 3$ were supported. However, the general school environment $(\beta=-0.011, \mathrm{t}=-0.142, \mathrm{p}>0.05)$ and students' learning attitude $(\beta=-0.056, t=-0.730, p>0.05)$ were not found to have a significant effect on student's favouring for private tutorial learning (H1 and $\mathrm{H} 4$ were not supported). Model-2 was obtained after introducing the moderator variable parents' affordability. With the inclusion of parents' affordability, the R-square value was improved by about $19.4 \%$, from $25.3 \%$ to $44.7 \%$. Interestingly, parents' affordability positively and significantly influenced students' intention to attend private tutorial learning $(\beta=0.469, \mathrm{t}=7.058, \mathrm{p}<$ 0.01 ) and therefore H5 was supported. It is worth mentioning that parents' affordability fully moderated the negative relationship between student's learning attitude and students' intention to attend private tutorial learning $(\beta=-0.117, \mathrm{t}=-1.759, \mathrm{p}<0.05)$, H6d was supported. However, parents' affordability partially moderated the 
relationship between social influence and students' intention to attend private tutorial learning (H6b was supported). There was no effect of parents' affordability on the relationship between rigidity of the school system, school environment and students' intention to attend private tutorial learning (H6a and H6c were not supported).

Table 4

\begin{tabular}{|c|c|c|c|c|c|}
\hline Hypothesis & Model-1 & $\begin{array}{c}\text { Standardized } \\
\text { Coefficients } \\
\text { Beta }\end{array}$ & t-value & $\mathrm{p}$-value & Decision* \\
\hline H1 & $\mathrm{GSE} \rightarrow \mathrm{PTL}$ & -0.011 & -0.142 & 0.887 & NS \\
\hline H2 & $\mathrm{SI} \rightarrow \mathrm{PTL}$ & 0.471 & 6.432 & 0.000 & $\mathbf{S}$ \\
\hline H3 & $\mathbf{R S} \rightarrow$ PTL & 0.190 & 2.319 & 0.022 & $\mathbf{S}$ \\
\hline \multirow[t]{3}{*}{$\mathrm{H} 4$} & $\mathrm{SLA} \rightarrow \mathrm{PTL}$ & -0.056 & -0.730 & 0.467 & NS \\
\hline & \multicolumn{5}{|c|}{$\begin{array}{l}\mathrm{R}^{2}=0.253 \text {, Adjusted } \mathrm{R}^{2}=0.232, \mathrm{~F}=12.109, \mathrm{p}=0.000 \\
\text { (ANOVA-I for Model-1) }\end{array}$} \\
\hline & Model-2 & $\begin{array}{l}\text { Standardized } \\
\text { Coefficients } \\
\text { Beta }\end{array}$ & t-value & p-value & \\
\hline H6a & $\mathrm{GSE} * \mathrm{PA} \rightarrow \mathrm{PTL}$ & -0.010 & -.148 & 0.883 & NS \\
\hline H6b & SI*PA $\rightarrow$ PTL & 0.362 & 5.577 & 0.000 & $\mathbf{S}$ \\
\hline H6c & $\mathrm{RS} * \mathrm{PA} \rightarrow \mathrm{PTL}$ & 0.096 & 1.334 & 0.184 & NS \\
\hline H6d & $\underset{\rightarrow \mathbf{P T L}}{\mathbf{S} \mathbf{L} \mathbf{A} * \mathbf{P} \mathbf{A}}$ & -0.117 & -1.759 & 0.046 & $\mathbf{S}$ \\
\hline \multirow[t]{2}{*}{ H5 } & $\mathbf{P A} \rightarrow \mathbf{P T L}$ & 0.469 & 7.058 & 0.000 & $\mathbf{S}$ \\
\hline & \multicolumn{5}{|c|}{$\begin{array}{l}\mathrm{R}^{2}=0.447, \text { Adjusted } \mathrm{R}^{2}=0.428, \mathrm{~F}=22.957, \mathrm{p}=0.000 \\
(\text { ANOVA-II for Model- } 2 \text { ) }\end{array}$} \\
\hline
\end{tabular}

Summary of Multiple Regression Analysis

*S-Supported; NS-Not Supported

\section{Effect of the moderating variable}

Recoding is a way to combine the values of a variable into fewer categories. In this case, to identify the moderating effect of parents' affordability, an ordinal scale (Low and High) was used based on the average value of 3.644. Figure 2 shows that there is a significant moderating effect between social influence and students' intention to attend private tutorial learning, as is also evident in Model-2 of Table 4. Hence, parents are highly influenced by their peers in favouring private tutorial learning for their wards. 


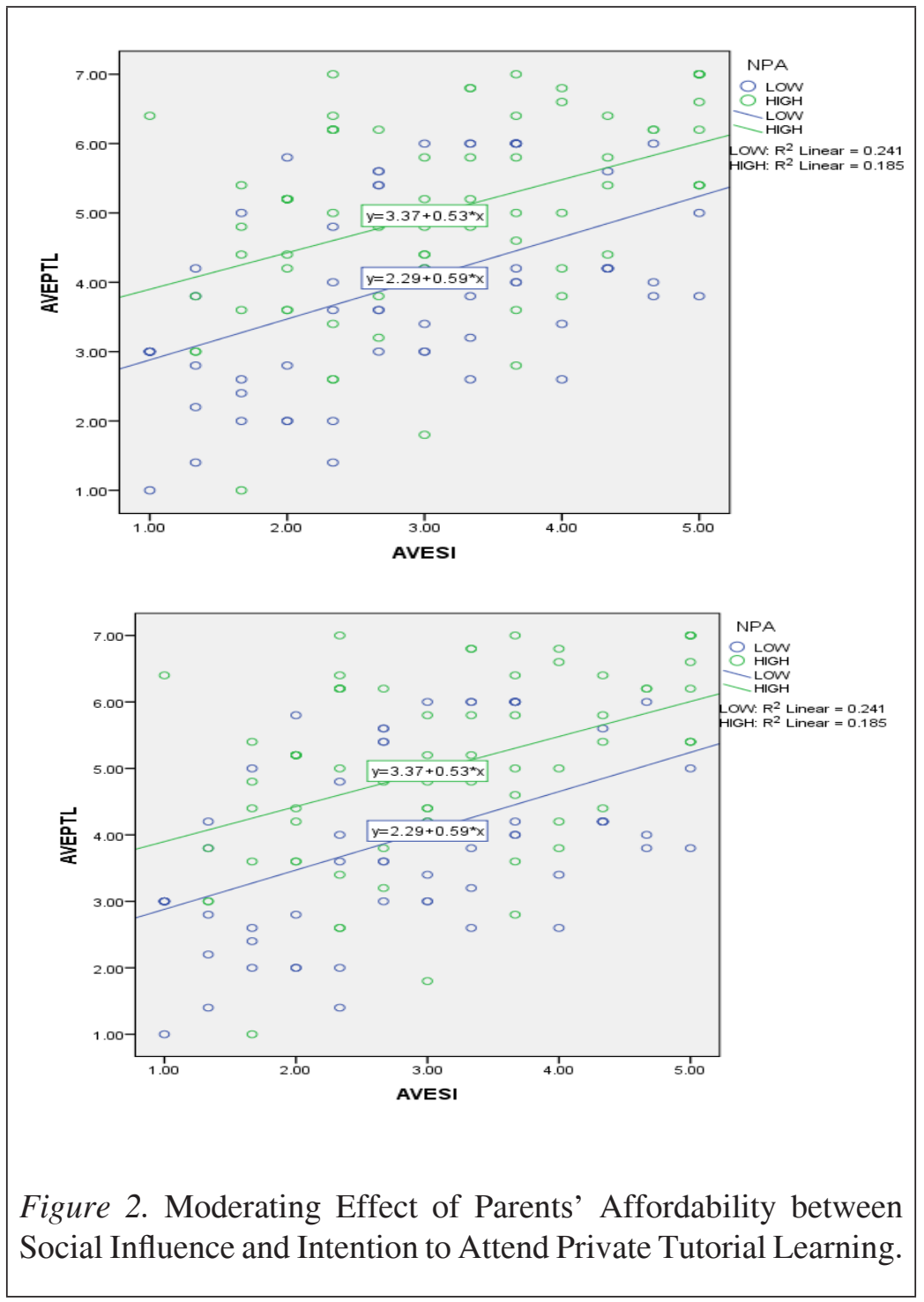

\section{DISCUSSION}

In this study, it was found that the general school environment was not influencing students' choice to attend private tutorial learning. The students stated that they were comfortable with the facilities in school for learning purposes. Also, teachers were able to facilitate students by helping them to solve their academic problems in school. 
Thus, the school environment was not a responsible factor in students' intention regarding private tutorial learning. Social influence, on the other hand, had a positive effect on students' intention to attend or continue private tutorial learning. Students agreed that private tutorial learning was a trend in the present education culture. They admitted that they enrolled in private tutorial learning only when their friends were also attending the tutorial class. In addition, friends would tend to exert influence among themselves to enrol in private tutorial learning. The rigidity of the school system was also found to have a positive effect on students' intention to attend or continue private tutorial learning. School hours in Malaysia start from early morning and ends in the afternoon; therefore, students felt it was convenient to attend private tutorial learning in the evenings. Further, since both parents were employed in most of the cases, students had no other option but to resort to private tutorial learning. Hence, if the school engages the secondary students till evening for library learning, then private tutorial learning would gradually reduce. The present study pointed to a negative relationship between students' learning attitude and the students' intention to attend or continue private tutorial learning, but the relationship was not found to be statistically significant. Some students attended private tutorial learning mainly because they wanted to increase their understanding of school subjects. Although, they can pay full attention in school and be well prepared before going to school, they would still enrol themselves to increase their study time and to look for more opportunities to practice. If the homework is practiced again in tutorial classes then it will become easier to understand (Das \& Das, 2013). Therefore, students' learning attitude was not found to be a main reason for attending private tutorial learning.

The present study has identified that parents' ability to afford private tutorials would have a significant positive influence on students' intention to attend or remain in private tutorial learning. Nowadays, both parents are employed and able to pay the tuition fees. Besides, parents want their children to do well in examinations and get the highest ranking in class. In the interaction with the moderating variable parents' affordability, the results of direct effects for general school environment and social influence remained the same. However, the results were reversed for the interaction of parents' affordability with the rigidity of the school system and students' negative learning attitude. The reason could be because wealthy 
families have the financial resources to send their children to private or international schools when the public schools are unable to satisfy their needs. Parents who can afford private school are willing to enrol their children there to improve their academic abilities (Neal, 1998; Kenayathulla, 2013). Despite the low annual income among a majority of the families in this study, $50 \%$ of the respondents in this study undertook tuition with minimum fees ranging from RM100 to RM200 per month for one subject.

Parents stress out their wards in the process of maximising their learning outcomes and potential. Parents are over ambitious and competition causes them to direct their children to attend private tutorial learning. The present Malaysian education system and the school system in particular play an important role in influencing students' intention to enrol in private tutorial learning. In addition, university entrance requirements include extracurricular activities in the calculation of qualifying marks. Students who are involved actively in extracurricular pursuits may miss academic lessons. Thus, students look to private tutors to help them to catch up with what they have missed.

\section{CONCLUSIONS AND RECOMMENDATIONS}

At the outset, the present study reveals that social influence and the rigidity of the school system are significant factors that impact upon students' need to attend private tuition classes. Schools can be somewhat inflexible in primary functional and operational areas. The school environment makes students mechanical and this ultimately results in lack of interest. The secondary school syllabus is overloaded, and having to complete the syllabus on time forces school teachers to forgo in-depth teaching and learning activities. Besides that, students are missing extra-curricular activities in school because of the rigid schedule. It is cautiously observed that rigidity in schools could be the root cause for non-creative and less innovative activities among some school going children. Ultimately, these students would find it difficult to cope with the present system in higher education. In the Malaysian culture, there is a tendency to be influenced by actions of group members, in the sense that if some parents are sending their wards for private coaching, others will follow suit. It is precisely the social influence which has an impact on 
student's favouring for private tutorial learning. Parental influence can sometimes have a stressful and traumatic impact on the learning abilities of students. Parents should realise that rather than importing education by force, creating a happy learning environment for their children is of utmost importance. It is suggested that parents should spend more quality time with their children and decide based on their own individual capacity whether private tuition classes are really required. At the same time, school authorities and policy makers would have to think more flexibly on matters relating to studentteacher ratio, extended study hours, establishing a strong foundation and extra-curricular activities. Unlike students in developed nations, school students in the Asian set-up must be oriented on the importance of higher education for career growth as higher education has great significance for employment opportunities.

\section{ACKNOWLEDGEMENT}

This research received no specific grant from any funding agency in the public, commercial, or not-for-profit sectors.

\section{REFERENCES}

Abdullah, M. A., Salim, S. S. S., \& Arip, M. A. S. M. (2018). Factors that influenced the problem of truancy among secondary school students. International Journal of Academic Research in Business and Social Sciences, 8(3), 343-353.

Ali, N., Isa, Z. M., \& Ibrahim, D. (2011). Malaysian education on implementation of quality assurance standard. In International Conference on Sociality and Economics Development, 10 (May), 479-83.

American Association of School Librarians, \& Association for Educational Communications (1998). Information power: Building partnerships for learning. American Library Association.

Bohan, H. (2007). Between identity and internationalisation: Vision and reality in the Malaysian education system (Unpublished doctoral dissertation). School of Applied Languages and Intercultural Studies, Dublin City University, Ireland. 
Bourdieu, P. (2002). The forms of capital. In N. W. Biggart (Ed.), Readings in Economic Sociology (pp. 280-291). Oxford: Blackwell.

Bray, M. (1999). The shadow education system: Private tutoring and its implications for planners. Fundamentals of educational planning No. 61. Paris: UNESCO International Institute for Educational Planning (IIEP).

Bray, M. (2010). Blurring boundaries: The growing visibility, evolving forms and complex implications of private supplementary tutoring. Orbis Scholae, 4(2), 61-73.

Bray, M. (2013). Shadow education: Comparative perspectives on the expansion and implications of private supplementary tutoring. Procedia - Social and Behavioral Sciences, 77, 412420.

Bray, M., \& Kwok, P. (2003). Demand for private supplementary tutoring: Conceptual considerations, and socio-economic patterns in Hong Kong. Economics of Education Review, 22(6), 611-620.

Burns, M. K., Senesac, B. V., \& Symington, T. (2003). The effectiveness of the hosts program in improving the reading achievement of children at-risk for reading failure. Literacy Research and Instruction, 43(2), 87-103.

Candeias, A. A., Rebelo, N., \& Oliveira, M. (2008). Student' attitudes toward learning and school-Study of exploratory models about the effects of socio-demographics and personal attributes. Retrieved from https://pdfs.semanticscholar.org/f7 28/910655d6b5b31d3470afc75eb4299e372b19.pdf

Cohen, P. A., Kulik, J. A., \& Kulik, C. L. C. (1982). Educational outcomes of tutoring: A Meta-analysis of findings. American Educational Research Journal, 19(2), 237-248.

Colvin, J. W., \& Ashman, M. (2010). Roles, risks, and benefits of peer mentoring relationships in higher education. Mentoring \& Tutoring: Partnership in Learning, 18(2), 121-134.

Crotty, J. (2012). Global Private Tutoring Market Will Surpass $\$ 102.8$ Billion By 2018. Retrieved October 30, 2019, from https:// www.forbes.com/sites/jamesmarshallcrotty/2012/10/30/ global-private-tutoring-market-will-surpass-102-billion-by2018/\#76cf03ea2ee0.

Dang, H. A., \& Rogers, F. H. (2008). The growing phenomenon of private tutoring: Does it deepen human capital, widen inequalities, or waste resources? The World Bank Research Observer, 23(2), 161-200. 
Das, G. C., \& Das, R. (2013). An empirical view on private tutoring in school mathematics of Kamrup District. International Journal of Scientific and Research Publications, 3(5), 1-8.

Dougherty, K. J., \& Hammack, F. M. (1990). Education and society. Washington DC: Harcourt Brace Jovanovich.

Dupriez, V., Monseur, C., Van Campenhoudt, M., \& Lafontaine, D. (2012). Social inequalities of post-secondary educational aspirations: Influence of social background, school composition and institutional context. European Educational Research Journal, 11(4), 504-519.

Economides, G., Philippopoulos, A., \& Sakkas, S. (2017). Tuition fees: User prices and private incentives. European Journal of Political Economy, 48 (June), 91-103.

Gara, P. \& Davis U. C. (2006). Peer group influence and academic aspirations across cultural groups of high school students. Center for Research on Education, Diversity, and Excellence. Retrieved from http//crede.berkeley.edu/research/sfc/3.5_ final.html.

Gök, F. (2010). Marketing hope: Private institutions preparing students for the University Entrance examination in Turkey. International Perspectives on Education and Society, 12, 123-134.

Goold, A., Coldwell, J., \& Craig, A. (2010). An examination of the role of the e-Tutor. Australasian Journal of Educational Technology, 26(5), 704-716.

Gordon, E. E., Morgan, R. R., Ponticell, J. A., \& O’Malley, C. J. (2004). Tutoring solutions for no child left behind: Research, practice, and policy implications. NASSP Bulletin, 88(638), 59-68.

Ha, T. T., \& Harpham, T. (2005). Primary education in Vietnam: Extra classes and outcomes. International Education Journal, 6(5), 626-634.

Hair, J. F., Sarstedt, M., Matthews, L. M., \& Ringle, C. M. (2016). Identifying and treating unobserved heterogeneity with FIMIX-PLS: Part I - Method. European Business Review. https://doi.org/10.1108/EBR-09-2015-0094.

Hon, H. N. (2010). Hong Kong's shadow education: Private tutoring in Hong Kong. The Hong Kong Anthropologist, 4, 62-85.

House, J. D., \& Wohlt, V. (1990). The effect of tutoring program participation on the Performance of academically underprepared college freshmen. Journal of College Student Development, 31(4), 365-370. 
Ille, S., \& Peacey, M. W. (2019). Forced private tutoring in Egypt: Moving away from a corrupt social norm. International Journal of Educational Development, 66, 105-118.

Ireson, J., \& Rushforth, K. (2005, September). Evaluating the impact of individual tutoring on GCSE attainment. Paper presented at the British Educational Research Association Annual Conference, University of Glamorgan, UK. Retrieved from http://www.leeds.ac.uk/bei/Education-line/browse/all_ items/153413.html

Jelani, J., \& Tan, A. K. G. (2012). Determinants of participation and expenditure patterns of private tuition received by primary school students in Penang, Malaysia: An exploratory study. Asia Pacific Journal of Education, 32(1), 35-51.

Kenayathulla, H. B. (2013). Household expenditures on private tutoring: Emerging evidence from Malaysia. Asia Pacific Education Review, 14(4), 629-644.

Kim, J. (2007). A game theoretical approach to private tutoring in South Korea. (Occasional Paper No. 144). National Center for the Study of Privatization in Education. New York: Teachers College.

Kim, J. H., \& Park, D. (2007). The determinants of demand for private tutoring in South Korea. Asia Pacific Education Review, 11(3), 411-421.

Kim, S., \& Lee, J. H. (2010). Private tutoring and demand for education in South Korea. Economic Development and Cultural Change, 58(2), 259-296.

Marsh, S. R. (2001). The history of tutoring in American higher education. Journal of the National Tutoring Association, 1(1), 19-36.

McArthur, D., Stasz, C., \& Zmuidzinas, M. (1990). Tutoring techniques in Algebra. Cognition and Instruction, 7(3), 197244.

Ministry of Education, Malaysia. (2006). Bil.1, 2006. Garis Panduan Kelulusan Melakukan Pekerjaan Luar Sebagai Guru Tuisyen atau Tenaga Pengajaran Sambilan. Kuala Lumpur: Author.

Ministry of Education, Malaysia. (2013). Private Institution Statistics. Retrieved from http://www.moe.gov.my/bps.

Neal, D. (1998). What have we learned about the benefits of private Schooling? Economic Policy Review, 4(1), 79-86.

Nunnally, J. C., \& Bernstein, I.H. (1994). The assessment of reliability. Psychometric Theory, 3, 248-292. 
Pallegedara, A. \& Mottaleb, K., A. (2018). Patterns and determinants of private tutoring: The case of Bangladesh households. International Journal of Educational Development, 59(March), 43-50.

Perkins, K. K., Adams, W. K., Pollock, S. J., Finkelstein, N. D., \& Wieman, C. E. (2005). Correlating student beliefs with student learning using the Colorado Learning Attitudes about Science Survey. In J. Marx, P. Heron, \& S. Franklin (Eds.), 2004 Physics Education Research Conference, AIP Conference Proceedings, Vol. 790 (pp. 61-64). Melville, NY: American Institute of Physics. doi:10.1063/1.2084701

Qian, D. D. (2014). School-based English language assessment as a high-stakes examination component in Hong Kong: Insights of frontline assessors. Assessment in Education: Principles, Policy \& Practice, 1-20.

Shah, S. Z. U., \& Farooq, M. S. (2009). Effect of School Library on Students' Learning Attitude. Online Submission, 24(1), 145-151.

Soh, K. L., Jayaraman, K., Lim, N. N., \& Chong, C. L. (2012). Have libraries in private institutions of higher learning in Malaysia lost their original purposes? What else does the evidence say about gender issues? International Journal of Education Administration and Policy Studies, 4(5), 127-132.

Steinberg, L. (1996). Adolescence. New York: McGraw-Hill Inc.

Sujatha, K. (2014, June). Private tuition in India: Trends and issues. Paper presented at the Colloque: L'éducation en Asie en 2014: Quels enjeux mondiaux? (International Symposium on Education in Asia in 2014: What global issues?) Revue Internationale d'éducation de Sèvres, Workshop 5. Retrieved from https://journals.openedition.org/ries/3913

Tansel, A. (2012). Private tutoring and the question of equitable opportunities in Turkey. IZA Discussion Paper No. 6626. Bonn, Germany: Institute of Labor Economics (IZA).

Tsang, M. C., \& Levin, H. M. (1985). The economics of over education. Economics of Education Review, 4(2),93-104.

Venezky, R. L., \& Jain, R. (1996). Tutoring for reading improvement: A background paper. America Reads Challenge Resource Kit. U.S. Department of Education.

Yan-Li, S., Roslan, S., Abdullah, M. C., \& Abdullah, H. (2018). Do family environment, parental care and adolescent externalizing problem mediate the relationship between parental readiness and adolescent school performance among commuter families? Community, Work \& Family. doi:10.1080/13668803. 2018.1504002 . 